\title{
Distance Education and Education Quality at HEIs in Ukraine During Covid-19
}

\author{
Tamara Bondar ${ }^{1 *[0000-0001-9484-9336]}$, Olena Varava 2 [0000-0002-2783-4932] \\ ${ }^{1}$ Mukachevo State University, Mukachevo, Ukraine \\ ${ }^{2}$ National University of Life and Environmental Sciences of Ukraine, Kyiv, Ukraine \\ *tamara_bondar@yahoo.com
}

\begin{abstract}
The article addresses the issue of the quality education provided by the teaching staff members at higher education institutions (HEIs) in Ukraine during the COVID 19 lockdown. It is a comparative study based on the survey conducted by the State Service for the Quality of Education in Ukraine that explained how HEIs transitioned to online teaching and learning in the spring semester of 2020. This study is a follow up, conducted in January 2021 to continue investigating trends and developments that characterized the autumn semester of 2020. The findings prove that although teaching staff members are emotionally challenged by the lack of technological skills and technology to teach online, the need to spend much time to develop online resources, about $92 \%$ of the faculty provided quality online teaching in the autumn semester of 2020. This was possible due to the organized HEIs management strategies that enhanced the transition to online teaching and learning as well as HEIs faculty professional attitude and motivation to overcome challenges that HEIs in Ukraine are currently facing. It is also concluded that HEIs need to reconsider approaches to allocate workload so that faculty could have more time for professional and personal development as well as be able to provide every student with individualized teaching. These factors are likely to become critical for enhancing quality education in Ukraine.
\end{abstract}

Keywords: Online teaching and learning, Teaching staff members, ICT infrastructure, Workload, Studentteacher ratio, Quantitative-focused study, Closed-ended questionnaire.

\section{INTRODUCTION}

The Resolution of the Cabinet of Ministers of Ukraine of March 11, 2020 № 211 “On prevention of the spread of the coronavirus (COVID-19) on the territory of Ukraine" marked a new period for the country and the system of education in particular. Secondary and higher education institutions urgently transitioned from traditional learning and teaching to distance learning and teaching following the guidelines in the Resolution. The State Service for the Quality of Education in Ukraine (hereinafter - the Service) administered an anonymous survey among higher education teaching staff and students to investigate how higher education institutions (hereinafter - HEIs) transitioned to distance learning caused by the coronavirus (COVID-19) in the period from March, 2020 to May, 2020 [[1]]. A total of 28,391 respondents took part in the survey among whom 22.367 were HEI students and 6.024 were HEI teaching staff members. The survey indicated the number and share of survey participants divided by the area of studies, types and forms of ownership of HEIs. Thus, the leaders among the represented areas in terms of the number of participants were Education / Pedagogy (19.14\% of students and $11.84 \%$ of teaching staff), Management and Administration $(9.51 \%$ and $8.42 \%$ respectively), Law (8.99\% and $6.18 \%$ ), Humanities (7.06 \% and $15.87 \%)$, Information Technology (6.95\% and $6.71 \%)$, as well as Culture and Art $(5.88 \%$ and $5.53 \%)$. The survey aimed at identifying achievements as well as drawbacks and pitfalls that Ukraine's system of higher education experienced during the lockdown period from March, 2020 to May, 2020. There were five major parts to analyse: HEIs strategies and management in the lockdown, teaching and learning organization, assessment / evaluation, ICT infrastructure at HEIs, and support given to teaching staff members at HEIs. While part of the survey was used as a foundation for further research to understand the context of the distance education, most questions in the proposed study investigated teaching and factors that had an impact on teaching at HEIs in Ukraine. 


\subsection{A Quality Education: Literature Review}

The term "quality education" has always been adjusted, narrowed, expanded, diluted, and concentrated so that its meaning could guide the system of education in reaching the goals. The quality education is the driving force that helps people to build more democratic, just and tolerant society. The Quality Education is Goal \#4 among the 17 Sustainable Development Goals ratified by the United Nations Organization [[2]]. The meaning of quality education focuses on the whole child development regardless of race, ethnicity, gender, socioeconomic status. It prepares our children for life teaching them soft skills in an emotionally and physically safe environment. There are three pillars that support a quality education including an access to highly qualified teachers, quality learning and teaching tools (pedagogy), and supportive learning environment. The content that the quality education provides is of great importance too, however, the factor that really matters for the quality education is how students deal with the content, if they are able to process, retain, and apply this information in real life. With the lockdown, the global education communities are reconsidering the factors that can have a huge impact on quality education. Many conferences were held to discuss the impact of COVID 19 on the education quality provided by HEIs. Many terms related to learning and teaching were re-introduced and highlighted to emphasize new features of education, for instance, virtual education, virtual education methodology, hybrid model, blended learning, remote teaching and learning, open format, virtual teaching, nonface-to-face teaching, virtual mobility [[3]] or video conferencing, computer-mediated teaching, synchronous video tools [[4]]. As Hassan, Mirza, and Hussain claim the quality education provides the long-term rescue for all the challenges. Therefore, in the pandemic time the educators throughout the world need to come up with alternative solutions to the traditional classroom teaching-learning. The scholars empathize the importance of professional development for the teachers to learn online platforms / tools, to acquire skills to handle the online ICT infrastructure in a challenging situation [[5]; [6]]. It is also noted that although HEIs are working hard to eliminate the educational losses caused by the lockdown by moving to the online platform, the availability of digital devices remains a major challenge in successful integration of online teaching especially in developing countries [[7]].

There is a bulk of research that investigates how to improve the quality education through prediction of student performance. Knowing the possible outcome of the learning process based on results of prediction collected through various software packages can help a HEI to motivate students by adjusting the factors that contributed to the past performance [[8]].
The study of the trends that characterize higher education in Ukraine compared to European and nonEuropean countries as well as factors that evidence these trends help to understand why Ukraine today faces the challenges providing quality education when transitioning to distance teaching and learning [[9]].

\section{METHODOLOGY}

The aim of the presented study is to explore the university teaching staff perception related to the quality of education in the period from September 2020 to January 2021. Findings characterising the Ukrainian higher education system in the period from March 2020 to May 2020 identified by the Service and related to quality of distance learning and teaching were used in this study to compare developments and identify current trends. There are 28 closed-ended research questions created in Google Forms and formulated to investigate the factors that might have an impact on the quality of education at HEIs in Ukraine. Teaching staff members answered questions pertaining advantages of distance teaching, the level of satisfaction instructors received from distance teaching, the range of distance teaching tools, the numbers of students who joined the distance class regularly, the frequency with which instructors administered online tests, the time taken to develop online tests, the share of students who regularly completed their home assignments and met deadlines, educators' perception of the level of student responsibility in terms of their studies, the level of student preparation for their classes, the amount of teacher workload, student-teacher ratio, and instructors' perception of the distance learning efficiency.

\subsection{Setting of the study}

This survey written in Ukrainian was targeted at HEI teaching staff in Ukraine. The online questionnaire in Google form was posted on the Facebook; it was also sent to HEIs in Kyiv, Lviv, Cherkasy, Drohobych, Khmelnytsky, Lutsk, Nizhyn, Mukachevo, Pereiaslav, Poltava, Rivne, Uzhgorod, and Ternopil. There were listed 29 areas of specialization of higher education institutions in Ukraine, including Education / Pedagogy, Management and Administration, Law, Humanities, Information Technologies, Culture and Art, Service Area, Health, International Relations, Social and Behavioral Sciences, Mathematics and Statistics, Public Administration, Veterinary Medicine, Civil Security, Electrical Engineering, Production and Technologies, Natural Sciences, Journalism, Transport, Agricultural Sciences and Food, Electronics and Telecommunications, Social Work, Mechanical Engineering, Military Sciences, National Security, Security State Border, Architecture and Construction, Biology, Chemical and Bioengineering, Automation and Instrumentation, and Theology. The highest percentage of responses was received from respondents employed in 
Education and Pedagogy accounting for $52.1 \%$, followed by Humanities at $17.6 \%$, Management and Administration standing at $7 \%$ and Social and Behavioral Sciences at $6.1 \%$. The percentage of other representatives is much smaller ranging from $0,3 \%$ to $2.4 \%$.

\subsection{Participants}

The participants in the study (330) were mainly females $(87.9 \%)$ who represented state owned HEI $(97.3 \%)$. In terms of the types of HEIs, $65 \%$ were universities, $29 \%$ were academies and/ or institutes, and the rest of respondents $(6 \%)$ represented colleges. With regards to age, almost $62 \%$ were respondents aged 3655 years old. While those who belonged to the youngest category (25-35-year-olds) made up $14.2 \%$, almost $20 \%$ of respondents were in the 56-65 age group. The proportion of people aged 66 and over was the smallest accounting for just $4 \%$. In terms of work experience related to teaching, the distribution was the following: the highest proportion of respondents (about $19 \%$ ) had up to 15 years of experience; almost similar proportion of respondents $(18,5 \%)$ taught up to 20 years at HEIs. Those who worked from 21 to 25 years and from 26 to 30 years at HEI accounted for $15 \%$ on average, respectively. Staff members with up to 35 years of experience made up $10 \%$, while $5 \%$ of staff had up to 40 years of experience. On the other hand, $5 \%$ of respondents accumulated from 41 to 50 years of experience while those with the fewest years of experience (up to 10 years) accounted for $13 \%$. Distribution of work experience is given in Table 1, where first line is number of years and the second line is the percentage of staff who worked for a number of years.

Table 1. Distribution of work experience by years (\%)

\begin{tabular}{|l|l|l|l|l|l|l|l|}
\hline $\begin{array}{l}\text { to } \\
10\end{array}$ & $\begin{array}{l}11- \\
15\end{array}$ & $\begin{array}{l}16- \\
20\end{array}$ & $\begin{array}{l}21- \\
25\end{array}$ & $\begin{array}{l}26- \\
30\end{array}$ & $\begin{array}{l}31- \\
35\end{array}$ & $\begin{array}{l}36- \\
40\end{array}$ & $\begin{array}{l}41- \\
50\end{array}$ \\
\hline $\begin{array}{l}13 \\
\%\end{array}$ & $\begin{array}{l}19 \\
\%\end{array}$ & $\begin{array}{l}18.5 \\
\%\end{array}$ & $\begin{array}{l}15 \\
\%\end{array}$ & $\begin{array}{l}15 \\
\%\end{array}$ & $\begin{array}{l}15 \\
\%\end{array}$ & $\begin{array}{l}10 \\
\%\end{array}$ & $\begin{array}{l}5 \\
\%\end{array}$ \\
\hline
\end{tabular}

\subsection{Data collection and data analysis}

Data collected were the answers to closed-ended questions. Some questions were taken from the State Service for the Quality of Education in Ukraine survey that was conducted in the spring semester of 2020. The answers to those questions allowed to compare the developments and changes in terms of information instruments used for online teaching. Other questions were developed by the authors to investigate the HEI teaching staff members' perception of the quality of their teaching and student performance. The questionnaire collected the responses for three weeks in January, 2021.

\section{RESULTS AND DISCUSSION}

The transition to online mode of teaching in the lockdown of the spring semester of 2020 was extremely urgent. Faculty had not time to prepare for the transition; they had to provide online teaching immediately. Taking into consideration that only $38 \%$ of respondents indicated a regular use of information technology before the lockdown, this figure could not and did not increase instantly. In the spring semester of 2020, $45 \%$ of respondents noted the regular use of information technology, while the number of those who taught regularly with online tools skyrocketed to $94 \%$ in the autumn semester of 2020. It is obvious that teaching staff skills to provide online teaching have improved substantially.

An extremely important indicator of quality teaching is the level of satisfaction that respondents feel when using information technologies to provide online courses. This question was measured by the five item Likert scale (completely satisfied, almost satisfied, 50/50, rarely satisfied, and never satisfied). It is evident that the lockdown enhanced technological skills instructors need to teach online, however, the issue of teacher's motivation remains questionable. While in both semesters of 2020 the percentage of those who were satisfied how they applied IT to teach online courses remained almost similar, at 91 and $92 \%$ respectively, the distribution of the proportions along the items changed. In the spring semester, $26.5 \%$ of respondents reported that they were completely satisfied with their online teaching, whereas this figure dropped almost by 10 points to $17 \%$ in the autumn of 2020 .

This decline could be explained by several factors. Firstly, $54 \%$ of respondents believed that the quality of student preparation experienced a decline. $54 \%$ of teachers also believed that students lacked responsibility completing their home assignments. It is proved by the responses in which $55 \%$ of instructors remarked that though online teaching seemed to provide more individualised learning and electronic journals allowed them to monitor student performance more regularly, these instruments did not seem to considerably improve student attitude to their online learning. In terms of completing assignments on time, $32.4 \%$ of respondents believed that half of all students failed to work regularly, which resulted in missing the deadlines when submitting their work. Another $12 \%$ believed that $60 \%$ of students worked properly. What is more, $19.7 \%$ of respondents claimed that $70 \%$ of students were regular with their studies. That results in a very low percentage of students who are really motivated to enhance their professional skills. In terms of quality, a very low proportion of instructors $(35.5 \%)$ reported that between $71 \%$ and $100 \%$ of students met the deadlines. Table 2 shows the findings related to instructors' statements on the number 
of students who met deadlines, completing their assignments.

Participants were asked to identify factors that prevented them from delivering quality distance instruction. The most significant factor indicated by the two-thirds of the surveyed in the spring of 2020 was the inability to have face to face communication with students. Inadequate technical provision at HEI was experienced by $41 \%$ of the surveyed while almost $38 \%$ claimed that they lacked technical skills. In terms of assessment, $26 \%$ of respondents questioned student academic honesty. In the autumn of 2020, the situation changed, and instructors (50\%) identified technical provision as the most important challenge that hindered the quality of teaching and learning. For instance, $34 \%$ of the respondents indicated that they did not have equipment to teach online from home. On the other hand, only $9 \%$ of instructors did not experience any technical problems.

Table 2. Students meeting deadlines

\begin{tabular}{|c|c|}
\hline $\begin{array}{r}\text { The number of } \\
\text { students who meet } \\
\text { the deadlines (\%) }\end{array}$ & $\begin{array}{c}\text { Instructor's beliefs related } \\
\text { to the proportion of students } \\
\text { who meet the deadlines }\end{array}$ \\
\hline $10-50$ & $32 \%$ \\
\hline $51-60$ & $12 \%$ \\
\hline $61-70$ & $19.7 \%$ \\
\hline $71-80$ & $17 \%$ \\
\hline $81-90$ & $16.4 \%$ \\
\hline $91-100$ & $2.1 \%$ \\
\hline
\end{tabular}

In the spring of 2020, commenting on advantages of online teaching, $49 \%$ of respondents identified selecting instructional materials, developing tasks, and using virtual educational environments as strengths. Following this, $36 \%$ thought that online teaching offered new qualitative approaches to teaching and learning organization. Enhancing student motivation, developing and using new techniques, using tools for assessment and self-assessment were indicated as advantages by about $25 \%$ respectively. In the autumn of 2020 , the responses changed. Using virtual educational environments (platforms) was ranked the most essential benefit by almost $60 \%$ of respondents. A number of participants who believed that online mode offered new qualitative approaches to teaching and learning increased from $36 \%$ in spring to almost $45 \%$ in the autumn of 2020 . The number of instructors who considered developing tasks and selecting new instructional material declined by $10 \%$, from $49 \%$ to $39 \%$. This could be explained by the fact that many universities put a lot of effort to organize online teaching and learning strengthening the online environment. For instance, when the lockdown started many universities set up a special department, responsible for online teaching and learning. At those universities where such departments had been set up before, their activity was enhanced to provide university faculty with necessary skills and offer them technical support. Although, HEIs have been solving this problem, the percentage of instructors who need additional training to provide quality teaching remains high. New digital technologies do improve learning outcome and enhance quality of education, however, to be implemented and produce changes they require digitally competent teachers [[10]].

The questionnaire also included the question about the time needed to develop a test using a web automated tool to ensure the quality education. The traditional hardcopy tests were not convenient to use for the online assessment. Although the advantages of automated assessment have been obvious, not many teaching staff members used the service. Consequently, only $20 \%$ of respondents confirmed that developing a Google form test took up to an hour. Another $34 \%$ took up to two hours. $22 \%$ of respondents needed three hours to develop a test, while the remaining $26 \%$ developed a test longer than 4 hours. That resulted in fewer tests administered by teachers, for instance, only $32 \%$ of respondents indicated that they administered a Google form test to every class or every second class, while $67 \%$ of the staff members gave a Google Form test $1-3$ times a semester. Failing to assess student performance regularly, teachers decrease student motivation for regular work. It is now evident that teacher's regular feedback on student performance provide a good incentive for learning [[8]].

Another important factor that influences the quality of teaching and learning is the student-teacher ratio, that is the number of full-time teaching staff members employed relative to the number of full time (daytime and correspondence) students enrolled. In terms of studentteacher ratio, only $7 \%$ of respondents reported that they worked with fewer than 50 students a semester. $52 \%$ claimed that the number of students per semester ranged from 51 to 100 students. The proportion of those who had from 101 to 160 students was $25 \%$. And $16 \%$ had to educate more than 160 students a semester. It is well known that staff-student ratio is a measure used by quality assurance agency to predict student success. It is also considered by many that HEIs with more staff to per student are more likely to create an interactive and engaged learning environment where every student could receive necessary support. The fewer students each instructor works with, the better they are able to tailor their teaching to satisfy student learning styles. With a lower student-teacher ratio, instructors are able to help those who are struggling to overcome learning obstacles. Lower student-teacher ratios do create a ripple effect that include fewer dropout students and higher qualification of graduates. On the other hand, budget constraints and cuts these days make HEIs in Ukraine to sacrifice the 
quality and search the ways to optimize the number of teachers per student by increasing it.

It is actually highly debatable if every student is able to receive necessary individual support. In Ukraine unlike many other countries, academic contracts are hours-based rather than task-based. Contracts of employments imply that workload of the HEIs teaching staff in Ukraine is 1542 hours annually with a 40 hour workweek, where about one third of the workload is made up of contact hours. The question about staff members workload evidenced that $70 \%$ of respondents worked from 450 hours to 800 hours (contact hours mostly) per year. While $20 \%$ were employed for less than 450 hours annually, $10 \%$ claimed their workload was 800 hours per year. If we add time necessary to prepare for classes by multiplying the workload by at least 2 (time necessary to develop syllabus, adjust the program, update material, develop tests), it is clear that even at this point staff are excessively overworked. It is also necessary to consider time for teaching staff members to manage other responsibilities like curriculum assessment, increased student assessment, teaching material development, repeated teaching sessions, research, and professional development. As many note, they do work about 100 hours per week far exceeding the officially set number of workhours. Depressed and overworked staff are unlikely to motivate students to reach the heights, to be able to ensure Ukraine's sustainable development. The increase in workload was reported by many other countries [[11]]. The reality is complicated, however, knowing it will help the country to face the problems and successfully overcome them. HEIs in Ukraine need to change university policies on workload allocation and develop a more effective model. There is a great need for a new approach to manage workload and terms of employment as it has to be flexible and consider individual and collective needs.

It is obvious that after almost a year of the lockdown the HEIs drastically changed. Traditional education has reached the point of no return and is looking for the ways to provide quality education and accommodate all students' needs. In this new context, HEIs have to continue cultivating high quality talents, create progressive thinking, inspire young people to explore; stimulate the development, that is to say, to retain its important social function - to ensure progress [[12]]. The answer at this point could be found in blended learning widely discussed by many educators [[13]].

\section{CONCLUSION}

Although there are some limitations to the study like much smaller sampling compared to the survey conducted by the State Service for the Quality of Education in Ukraine, it was conducted in the right period of time, covering the autumn semester of 2020 and just following the national survey. Such approach allows identifying the changes and trends that characterize modern HEIs in Ukraine. The main goal of the study was to examine the quality education issues in the pandemic period, caused by the COVID 19 lockdown. The findings allow reaching several conclusions related to the issue. Firstly, although the transition to online teaching and learning in Ukraine was hasty, without necessary preparation, it took several months for $92 \%$ of teaching staff members to acquire information communications technology skills to provide online teaching. The range of instruments teachers learned expanded; the fear of technology was overcome. Secondly, HEIs in Ukraine do value education and focus on enhancing its quality. Since having ICT infrastructure became the key factor for the HEI to be competitive in the pandemic time, a lot of strategic planning was put into action to enhance the HEI learning environment: the online platforms were purchased or activated, webinars were provided to help staff to learn new ICT instruments. Thirdly, it was proved that teachers remain the key issue in providing quality education, however, challenged by the COVID 19, teaching staff have to continue learning instruments and experimenting with platforms to use online teaching benefits to the full extent. Finally, in order to provide the quality education, the HEI administration has to reconsider the workload policy, student-teacher ratio, and teacher obligations that will make HEI environment more conducive for professional development of teaching staff members, enhance their creativity and efficacy for overcoming challenges.

The future studies are likely to investigate the changes in teaching staff workload, the approaches to overcome pressure, and ways to enhance distance teaching and learning.

\section{AUTHORS' CONTRIBUTIONS}

Authors contributed equally to conduct the research study and explain the findings.

\section{ACKNOWLEDGMENTS}

The authors express their gratitude to colleagues who offered constructive feedback required for developing a questionnaire. They would also like to acknowledge all respondents from HEIs in Ukraine, who supported us by taking their precious time to complete the questionnaire and helping the authors to complete this study.

\section{REFERENCES}

[1] The official site of the State Service for the Quality of Education in Ukraine (2020), Informatsiynoanalitychna dovidka pro rezultaty opytuvannya shchodo stanu vykorystannia tekhnolohiy dystantsiynoho navchannia u zakladakh vyshchoyi osvity, available at: https://cutt.ly/ukvejVC, (Accessed January 15, 2021).

[2] United Nations (2015), Transforming Transforming our world: the 2030 Agenda for 
Sustainable Development, available at: https://www.un.org/ga/search/view_doc.asp?symb $\mathrm{ol}=\mathrm{A} / \mathrm{RES} / 70 / 1 \& \mathrm{Lang}=\mathrm{E}$, (Accessed January 15, 2021).

[3] UNESCO (2020) Impact of the covid-19 coronavirus crisis in higher education: responses to the emergency and digital transformation of higher education, available at: https://www.iesalc.unesco.org/en/2020/08/18/impa ct-of-the-covid-19-coronavirus-crisis-in-heiresponses-to-the-emergency-and-digitaltransformation-of-higher-education/, (Accessed January 15, 2021).

[4] Mukan, N. and Lavrysh, Y. (2020), "Video Conferencing Integration at Universities: Challenges and Opportunities", Revista Romaneasca pentru Educatie Multidimensionala, vol. 12 (1Sup2), pp. 108-114. DOI: https://doi.org/10.18662/rrem/12.1sup1/253

[5] Hassan, M.M. Mirza, T. and Hussain, M.W. (2020), "A Critical Review by Teachers on the Online Teaching-Learning during the COVID19", International Journal of Education and Management Engineering, vol. 10, no. 5, pp.17-27. DOI: $10.5815 /$ ijeme.2020.05.03

[6] Provorova, Y.M. Ivakhnenko, T.P. Oliinyk, N.A. Atroshchenko, T. O. and [et al.] (2021), "Development of the Emotional Stability Seen as a Personal Leadership Quality Using the Acmeological Approach in the Master's Students", European Journal of Educational Research: research journal. Hanover, USA, vol. 10, Issue 1, pp. 275-284.

[7] Amjad, M. and Linda, N.J. (2020), “A Web Based Automated Tool for Course Teacher Evaluation System (TTE)", International Journal of Education and Management Engineering, vol. 10, no. 2, pp. 11-19. DOI: $10.5815 /$ ijeme.2020.02.02

[8] Ahuja, S. Kaur, P. and Panda, S.N. (2019), "Identification of Influencing Factors for Enhancing Online Learning Usage Model: Evidence from an Indian University", International Journal of Education and Management Engineering, vol. 9, no. 2, pp. 15-24. DOI: 10.5815/ijeme.2019.02.02

[9] Bondar., T.I. Telychko, N.V. Tovkanets, H.V. Shcherban, T.D. and Kobal V.I. (2020), "Trends in Higher Education in EU Countries and non-EU Countries: Comparative Analysis", Revista Romaneasca Pentru Educatie Multidimensionala, vol. 12 (1Sup1), pp. 77-92. DOI: https://doi.org/10.18662/rrem/12.1sup1/224
[10] Hassan, M.M. and Mirza, T. (2021), “The Digital Literacy in Teachers of the Schools of Rajouri (J\&K)-India: Teachers Perspective", International Journal of Education and Management Engineering, vol. 11, no. 1, pp. 28-40. DOI: 10.5815/ijeme.2021.01.04

[11] Hussain, M.W. Mirza, T. and Hassan M.M. (2020), "Impact of COVID-19 Pandemic on the Human Behavior", International Journal of Education and Management Engineering, vol. 10, no. 5, pp. 35-61. DOI:10.5815/ijeme.2020.05.05

[12] Qi-Ming, W. Xi-nan, Z. and Li-li, Z. (2013), “A Novel Thought and Method of University Evaluation", IJEME, vol. 3, no. 2, pp. 59-65.

[13] Khine, P.T.T. Win, H.P.P. and Naing, T.M. (2021), "Towards Implementation of Blended Teaching Approaches for Higher Education in Myanmar", International Journal of Education and Management Engineering, vol. 11, no. 1, pp. 19-27. DOI: 10.5815/ijeme.2021.01.03 